\title{
Location, location, relocation: how the relocation of offices from suburbs to the inner city impacts commuting on foot and by bike
}

Ray Pritchard ${ }^{*}$ (D) and Yngve Frøyen

\begin{abstract}
Purpose: In recent decades there has been increasing focus on the development of compact and accessible urban environments, in part based on the reasoning that this can help to reduce the transportation requirements of city residents. Travel intensive land uses such as office workplaces are often offered incentives from policy makers to relocate to central locations well served by public transport (transit oriented development). To date, the academic literature on integrated transport and land use planning has largely been focused on the reduction of private car usage and promotion of public transport. This paper adds a complementary dimension, testing the hypothesis that intra-city workplace relocation towards city centres promotes walking and bicycling.
\end{abstract}

Methods: This paper uses a comparative case study method. Employee travel surveys were conducted before and after the 2015 relocation of an office workplace in Trondheim, Norway from urban periphery to city centre. Three similar office relocation cases in Trondheim and Oslo (post-2000) are used for comparison to the case study. Changes in travel distance, time, costs, optimal route and potential for walking and bicycling in the case study are considered alongside actual changes in transport mode.

Results: Walking and bicycling levels have a clear inverse relationship with distance to the city centre, due in large part to reduced commuting distances and increased parking costs following relocation. For the case study, the modal share of walking and cycling increased by a factor of 2.5 and 2.8 respectively. Relocation similarly led to a tripling in the number of case study employees who have a commute distance of less than $6 \mathrm{~km}$, the employees' median acceptable cycling distance. Active commuting levels from the former and current workplace locations match closely with the share of active commuting in the Norwegian National Travel Survey data for the corresponding neighbourhoods.

Conclusion: Although the function of workplaces and their employees can vary significantly within a city neighbourhood, travel behaviour is to a large extent determined by supply variables like time and cost. Central workplace locations with good public transport accessibility are shown to create significantly improved opportunities for walking, cycling and public transport commuting compared to peripheral workplaces with little competition to workplace accessibility by car.

Keywords: Relocation, Office, Commuter mode choice, Bicycle, Pedestrian, Densification, Centralisation

\footnotetext{
* Correspondence: Ray.Pritchard@cantab.net

Department of Architecture and Planning, Faculty of Architecture and

Design, NTNU—Norwegian University of Science and Technology, 7491

Trondheim, Norway
} 


\section{Introduction}

The importance of accessibility on the travel patterns of urban dwellers is well documented through comparisons of cities, city districts and even suburbs [1]. However, there is somewhat less research concerning the travel behaviour changes resulting from the intra-city relocation of transport-attracting land uses such as workplaces. Considering that some studies suggest between 6 and $8 \%$ of all companies relocate each year [2], there has been relatively little research concerning the commuting impacts of such relocations, especially in the direction towards the city centre. Previous research has been mostly focussed on the relocation of workplaces in the opposite direction: to suburban areas in line with a decentralisation trend that amongst developed countries was more evident several decades ago. This paper makes contributions to the travel behaviour literature on the relocation of workplaces to city centres, using cases from Norway.

Although the reasons for relocating a workplace are many and varied, one typical benefit of relocating closer to the inner city is an improvement in both active and public transport accessibility, for both employees and visitors alike. For employees, a change from car-based commuting to walking or cycling to work significantly increases the net amount of physical activity they receive in an average week [3-5]. Since inner city real estate prices are typically higher than in the suburbs, the relocation of a workplace from city outskirts to inner city tends to result in reduced access to free car parking. Although the theoretical car accessibility for the labour force may be better or approximately equal in the inner city, congestion effects and reduced free parking work as discouragements for car-based commuting. In this manner, workplace relocation can work as both a carrot and stick initiative for employees to make a switch from commuting by car.

This paper employs a comparative case study method in an attempt to better understand the various phenomena that impact active commuting levels when workplaces relocate towards urban centres. Empirical travel survey data has been collected before and after the 2015 relocation of a newspaper publishing office, Adresseavisen in Trondheim, Norway. A search of academic and grey literature for other cases from Norwegian cities was performed resulting in the addition of three other workplaces that relocated to areas closer to the centres of Trondheim and Oslo since 2000. Commuter travel behaviour for the three additional cases is extracted from existing Norwegian reports. The most recent of these reports concerns an insurance company Gjensidige in Oslo, which relocated its headquarters in 2013 [6]. The municipal administration staff in Trondheim were relocated in 2005 from three clusters to a single cluster in the city centre [7]. In a similar vein, the
Trondheim-based public office Statens Hus for public roads administration workers and county employees in Sør-Trøndelag was relocated in $2000[8,9]$. Each of the existing reports discusses the changes in employee transport mode to work before and after the respective workplace relocation.

\section{Background}

This study focuses upon relocation towards city centres as a result of a reversal in land use policies that catered for the exact opposite: decentralisation or suburbanisation. Most city regions have grown enormously in land use area since private car ownership became affordable. Mass private motorisation in the 1950 s and 1960s contributed to widespread traffic congestion and increased pollution in urban areas across much of North America, Europe and Australia. Planners at the time observed this mismatch in supply and demand of public space and began major road and highway expansions, thus increasing the urban footprint. In time, this allowed for the introduction of employment decentralisation policies under the logic that this would reduce both traffic flows through overloaded city centres and the distance between employers and their workforces [10].

The vast majority of literature concerning company relocation has been focused on movement away from the city centre to the suburbs or more general trends towards suburbanisation. This applies equally for studies performed outside of Norway ([10-19]; Geographic Institute of Utrecht University 1990 in [20]) to those within Norway [21-28]. Common findings across all studies are increased car modal share - typically a result of reduced public transport accessibility and favourable car parking allowances at the suburban location [17, 20, 23, 27]. Interestingly, the increase in car use at the expense of all competing modes was also witnessed for a suburban relocation in which the average distance between the employee residences and place of work decreased [11]. A study which followed up the commuting behaviour of more than 7000 employees across 42 London offices postrelocation showed that car modal split increases slightly in the 7 years following decentralisation to the outskirts of London [14]. This finding is echoed for two Norwegian follow-up surveys in Trondheim [28] and Oslo [29].

A relatively small proportion of the international literature is devoted to companies relocating towards the city centre (City of Copenhagen 1993 in [29]; [2, 30, 31]). These studies are discussed in more detail in section 5. Amongst Norwegian studies of company relocation, a somewhat higher proportion are focussed on moves towards the city centre $[6,7,9,26,29,32]$. 
Three of the Norwegian relocations $[6,7,9]$ are chosen for case-comparison analysis based on their similarity to the Adresseavisen case study introduced in this paper. Criteria for case selection was that the comparative relocations occurred in or after the year 2000 and with a comparable change in distance from suburbs to the city centre.

Although the majority of cities still have a cluster of employment functions in the city centre, many have suburban mixed-use centres that combine residential and workplace functions. To better understand the relationship between central and suburban workplace location, existing research has measured commuting behaviour using outcomes such as trip frequency, trip length, mode choice and Vehicle Kilometres Travelled (VKT) [33]. Commuting distance, or trip length, has additionally been measured in many studies of urban form and travel behaviour. Næss [34] found that central workplaces in Oslo and Copenhagen had shorter commute distances compared to their suburban counterparts whilst equivalent locations in Helsinki had longer. However, Norwegian National Travel Survey (NNTS) data from 2009 comparing regions within Oslo showed that employees working in the city centre have slightly longer commutes than the city average [35]. It should be noted that commute distance is to a large extent affected by the specialisation of the workplace, and so the sample of workplaces is critically important for the outcome of such analyses.

Since commute distance has a number of weaknesses as a metric, comparison-based articles have begun to make use of the composite travel measure Vehicle Kilometres Travelled (VKT - alternatively called VMT when miles are used). VKT reflects changes in both spatial variables, such as average distance, and modal changes like increased nonmotorised transport usage ([10]). The extensive meta-analysis from Ewing and Cervero [33] concludes that VKT is most strongly related to destination accessibility relative to other built environment measures, meaning that areas with good active and public transport accessibility such as inner cities produce lower VKT than suburban mixed-use centres.

A review of Nordic literature regarding workplace relocation shows increases in public and active transport use for central workplace location relative to suburban locations across all of the applicable studies [34]. This said, national travel survey data from nine Norwegian cities in 1984-1985 shows the rate of walking and cycling increases in the urban area excluding the city centre (combined modal share of $24 \%)$ relative to the city centre (12\%) [36]. This, reason Strand et al., was most likely due to structural differences in workplaces whereby more peripherally located businesses recruit their workers locally to a greater extent than centrally located businesses (as cited in [37] p. 5).

Whilst there are many other studies comparing the travel impacts of different workplace locations, they tend not to control for self-selection influences (whereby businesses in the same manner as residents may choose to locate in a particular area independent of built-environment influences). It is possible to control for this influence by observing short-term changes resulting from workplace relocation - in this case in the less studied direction: towards the city centre. This paper compares four such relocation cases in Norway.

\subsection{Norwegian planning context}

Norway has been early in its adoption of sustainable development policies, something which is reflected by the leadership of former Norwegian prime minister, Gro Harlem Brundtland, in authoring the Our Common Future report [38]. Densification and compact urban development policies are now commonly utilised in metropolitan areas across Norway. Such policies can be considered a response to the practice of decentralisation of compact transport intensive workplaces, both between cities and within cities in Norway up until the early 2000s [23, 24, 28, 29, 37, 39].

Increased focus upon the interactions between land use, urban form and transportation was the trigger for a reversal in urban development policy, beginning formally with the introduction of the first national guidelines for integrated land use and transport in 1993 [40]. Today, the planning guidelines for integrated housing, land use and transport planning are referenced in the Norwegian Planning and Building Act. The Act includes the same key policies from 1993 through the inclusion of a compact city clause: "The development patterns and transport system should promote the development of compact cities and urban areas, reduce transport requirements and facilitate the use of sustainable transport modes" ([41], sec. 3). It goes further to state: "Effective traffic management and good accessibility for business-related transport must be prioritised in the planning process" [Ibid. sec.4.6].

Oslo and Trondheim are the two cities of interest in this paper. The nation's capital city Oslo is by far Norway's largest city whilst Trondheim is the fourth largest urban metropolitan region in Norway (after Oslo, Bergen and the Stavanger-Sandnes metropolitan area).

A modernistic urban development plan for Oslo was adopted in 1950 [42]. Zoning regulations separated city 
functions such as housing and workplaces whilst dispersion favoured car use. However, it was not until the second revision in 1991 that densification was addressed and 1994 before the local centre hierarchical structures were re-evaluated to address integrated transport accessibility requirements [Marianne Knapskog: Accessibility in Norwegian urban planning Dutch $\mathrm{ABC}$ location policy in Norwegian integrated land use and transport planning ( $\mathrm{PhD}$ thesis), forthcoming]. Today Oslo is growing faster than the other major cities in Norway, a contributing factor to its higher rate of densification compared to the three next-largest cities of Bergen, Stavanger and Trondheim [43]. Oslo has additionally increased its levels of active and public transport users most of the four cities in the period from 2001 to 2009 [Ibid. p.99].

In Trondheim, the importance of workplace location first came into focus during the regional transport plan development in the 1960s [24]. This is unsurprising given the removal of car import restrictions to Norway in 1960. It was during this period that planners realised that the expected commercial growth and car use would lead to far more car traffic than it was possible to manage through the city centre. This was a key factor contributing to the establishment of a regional centre at Heimdal, approximately nine kilometres south of the city centre of Trondheim ([24], p. 102). Dutch-inspired ABC planning policies have been practised in Trondheim since the late 1990s with a focus on "the right business in the right place" regarding its strategy for business growth and workplace development [28]. With regards to transport, the municipal master plan for Trondheim introduced in 2008 a target to increase the modal share of environmentally friendly transportation from $42 \%$ to $50 \%$ for all urban journeys by 2018 ([44], p. 70). The plan states that a minimum of $60 \%$ of new office workplaces should be built along the primary public transportation arc, a goal that was introduced by city planners in 2008 [ibid., p.62]. The most recent data from the years 2001 to 2010 indicates that $65 \%$ of all newly built offices have met this spatial criterion [ibid. p.63].

The return of workplaces from suburban localities to city centres is in part a result of integrated transport and land use policies - both at the national and city level. Depending on the workplace function, there may additionally be many other reasons for relocation, such as business image, agglomeration benefits, floor space costs and changes in employee numbers $[45,46]$. Whilst individual differences will always affect the spatial location of a workplace, urban planning policy can have wide-reaching and long-lasting effects on the localisation of employment within cities.

\section{Methods and introduction to cases}

This paper takes inspiration from existing research looking at interactions between land use and transport in the context of workplace location. By accumulating research from Norway on central workplace relocations, it is possible to observe active transport outcomes in relation to changes in accessibility, business structure and economic factors like parking. In addition to reviewing the literature on workplace relocations, this study makes use of a before and after survey in connection with the central relocation of the Trondheim-based newspaper Adresseavisen. The newspaper's existing and new office locations are shown in Fig. 1, together with the two other Trondheim relocation cases: Trondheim Municipality and Statens Hus. Fig. 2 meanwhile shows the former and present locations of the Oslo-based headquarters of insurance company Gjensidige that similarly relocated their premises from the suburbs to the inner city. Public transport accessibility is displayed in the background of Figs. 1 and 2, in order to provide contextual information for these cities. Public transport accessibility is calculated as the average public transport travel time from any given origin to a raster grid of all potential destinations within a city.

\subsection{The case study: Adresseavisen}

Adresseavisen, Norway's oldest newspaper and Trøndelag County's largest, relocated its primary office from Heimdal, $10 \mathrm{~km}$ south of the centre of Trondheim, to Verftsgata near Solsiden, one kilometre east of the city centre in June 2015. In connection with the relocation, an online travel survey was distributed via e-mail to approximately 300 employees in June 2015 and June 2016. The 2015 before-survey was distributed two weeks prior to the office relocation. The repetition of the survey after one year allowed for the settling of travel routines after the relocation. The same approach was used in the three other cases. Resampling at the same time of year ensures seasonal comparability, a factor which can otherwise have significant impacts on Norwegian commuter travel behaviour, especially for pedestrians and cyclists.

The before and after surveys contained questions about commuting behaviour on the day of the survey, as well as most common travel patterns in the summer and winter months. It additionally asked respondents to estimate the travel impacts of the office relocation and to recall their existing behaviour in the before and after surveys respectively. Respondents were also asked to list the location of an intersection near to their home, whilst answering questions concerning demographics, their willingness to bicycle/walk to work and their access to and costs associated with different transport modes. 


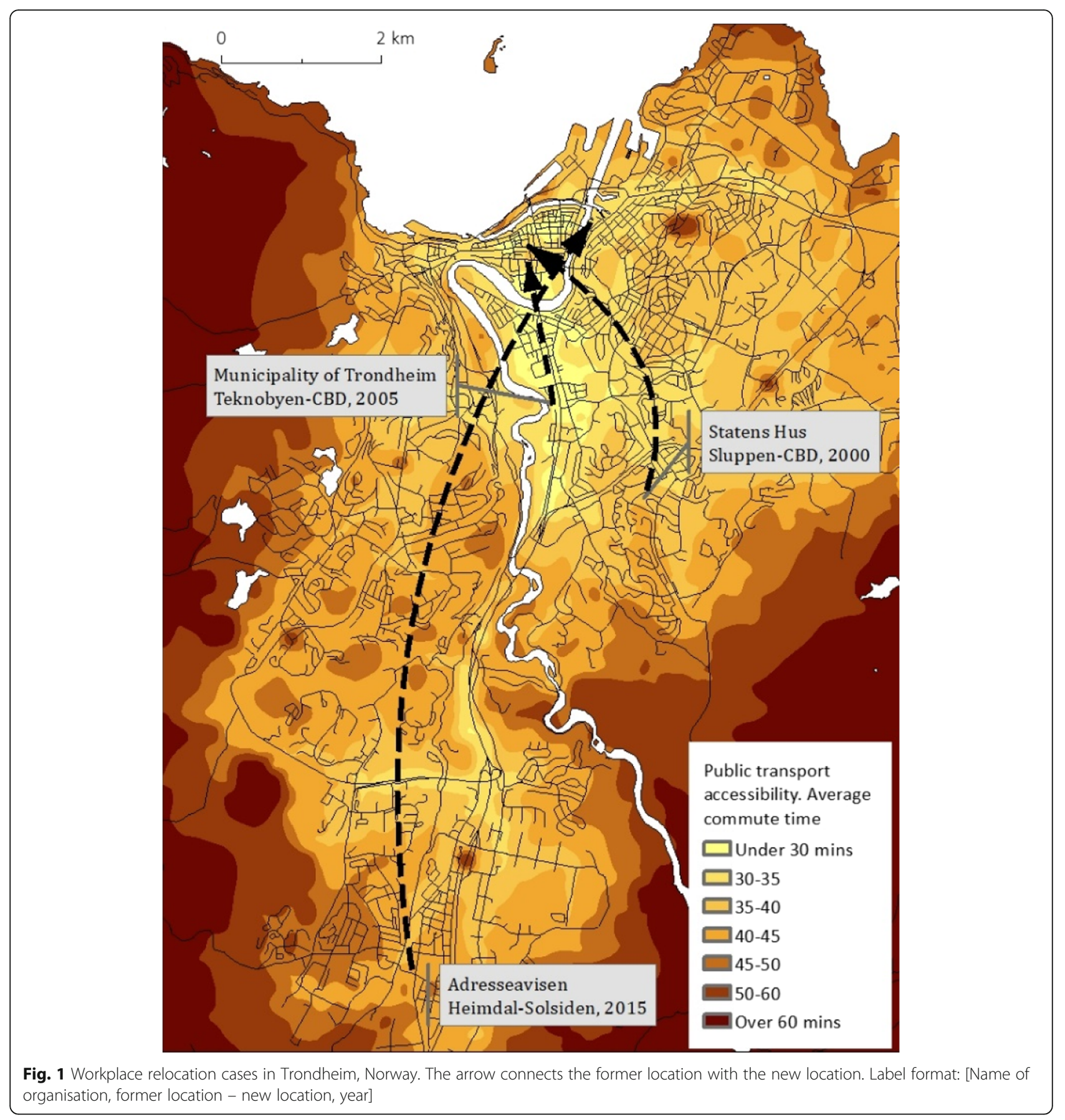

\subsection{Norwegian comparison cases}

The literature concerning Norwegian workplace relocations and commuting behaviour was assessed to find suitable cases for comparison to the Adresseavisen case study used in this article. Three existing before-after studies between 2000 and 2016 were found concerning the travel impacts of relocation toward city centres in Norway. These three cases from the cities of Trondheim and Oslo are described below. In addition, nine other cases were found, mostly using the same before-after travel survey methodology to assess commuting changes following workplace relocation. Two of these were related to relocation towards the city centre of Oslo but were excluded from the comparative cases due to their age (pre-2000). Changes in active and public transport mode for each of the altogether 12 existing Norwegian relocation studies are summarised in the Appendix.

Statens Hus, a public office in Trondheim co-located their offices to the city centre from three different clusters, 


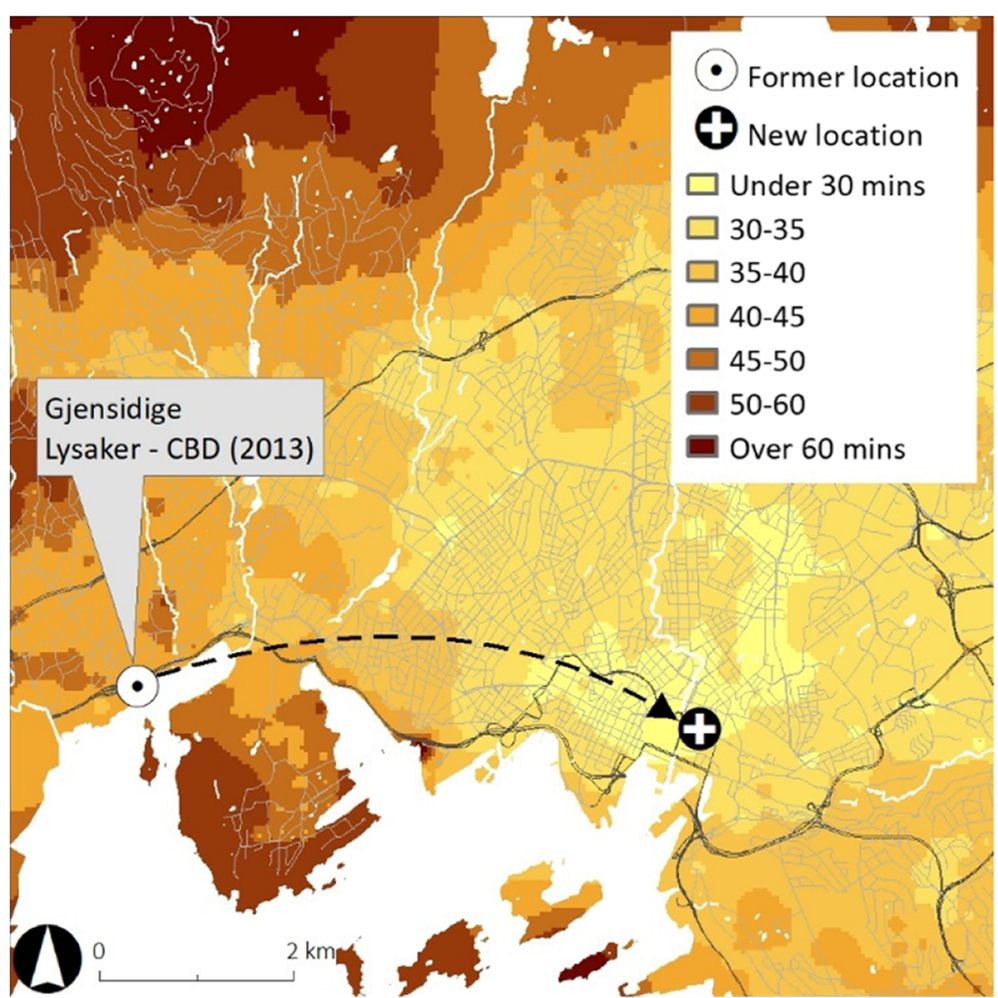

Fig. 2 The former and new locations (see the label and arrow direction) of the insurance firm Gjensidige in Oslo

two of which were located approximately four kilometres south of the city centre (Sluppen) in 2000 [8]. The approximately 500 public servants were split between two different organisations: the county of Sør-Trøndelag and the Norwegian Public Roads Administration. In addition to employee survey data from 2000 and 2001, follow-up surveys were performed in 2004 and 2012 to observe long-term effects of relocation. Free parking that was previously available to all employees was reduced by half, whilst the remaining employees had the opportunity to pay for public parking themselves at an average cost of 65 kroner $(7 €)$ per day.

Trondheim Municipality relocated nearly 1000 administrative employees from 3 building clusters located between one and four kilometres outside of the Trondheim centre to a single cluster immediately adjacent to the relocated Statens Hus in 2005/2006 [7]. A travel survey was performed in September 2004 and 2006. Prior to relocation, there were sufficient car parking spaces for half of all employees, mostly free. This reduced to 35 places, with only a small fraction reserved for political or administrative leaders. The remainder were available for 700 kroner/ month $(75 €)$ to employees who could demonstrate need (due to temporary mobility impairment, pre-school aged children etc.).
A Norwegian insurance firm Gjensidige, relocated its headquarters with nearly 1000 staff from Sollerud, six kilometres outside of Oslo, to the Oslo city centre in 2013 [6]. After a previous abundance of parking space in the former location, Gjensidige was only able to offer 1.6 parking spaces per $1000 \mathrm{~m}^{2}$ of floor space at the new location in accordance with the local parking norms. These had to be reserved in advance (due to their low availability), otherwise employees who drove were expected to find parking elsewhere. The nearest multi-storey car park charged 240 kroner/day (26€). Meanwhile $7 \%$ of the employees who previously drove stated that they had access to free street parking after the relocation, presumably further from the city centre.

Gjensidige is an interesting case as its prior relocation out of the city centre is also well documented. In 1991, Gjensidige co-located 1200 staff from its eight offices spread across the Oslo city centre to the single suburban complex at Sollerud [23]. The peripheral relocation came towards the end of a period where the relocation of companies to the urban periphery was a relatively common occurrence in Norway [24, 28, 29, 37]. Whilst only located $8 \mathrm{~min}$ walk from the Lysaker train station, the public transport accessibility decreased considerably compared to the Oslo city centre. Simultaneously, the number of employees with access to free parking increased from $6 \%$ to $43 \%$. Active transport usage was unaffected by 
the change, however, the use of public transport dropped by $31 \%$ compared to the former situation.

In total, 12 Norwegian intra-city workplace relocation studies are summarised in the Appendix (encompassing relocations both in and out of the inner city).

\subsection{Commute distance and travel time estimation for Adresseavisen}

In the absence of revealed preference route choice information from the two employee surveys conducted amongst Adresseavisen employees, this paper calculated shortest paths as a proxy for the commuting distance and travel time for different transport modes. Origins are the home addresses (provided as the nearest street intersection) of unique employees, whilst the two destinations are the former and new locations of Adresseavisen. Whilst car and pedestrian journeys are modelled by optimising Dijkstra's shortest path algorithm [47], bicycle trips are routed on a traffic stress weighted transport network allowing the prioritisation of routes suitable for cycling (for a given distance trade-off). Public transport journeys are modelled in terms of combined access/egress time, waiting time (defined as half the time between consecutive departures) and travel time.

Bicycle journeys are routed in a Level of Traffic Stress (LTS) weighted transport network in order to allocate increased impedance upon streets poorly suited for cycling $[48,49]$. LTS is loosely based on the Dutch CROW Design Manual for Bicycle Traffic [50], whereby road segments are classified in four levels from one to four (LTS 1 has the lowest traffic stress) according to their degree of separation from other road users [49]. Separation is defined in terms of both physical infrastructure, such as the provision of bicycle paths, approximate volumes of traffic and in terms of posted speed limit (affecting the safety and number of overtaking manoeuvres).

The approach used for converting LTS levels into optimised bicycle routes is adapted from existing research [48]. Segments in the transport network with high LTS are least attractive and are therefore allocated a higher impedance factor - equivalent to the maximum detour rate bicyclists are willing to take. For this study an impedance factor of 1.20 was used, indicating routes up to $20 \%$ longer in distance are considered as potential options. The detour rate is selected based on a route choice model that found that cyclists are willing to cycle up to $19 \%$ longer for a commuting journey if they are able to use a bicycle path [51]. GPS-based research in Oslo, Norway reveals mean bicycle detour rates of $21 \%$, median of approximately $12 \%$, whilst 85 th percentile detour rates equated to $30 \%$ longer trips [52]. The skewed distribution in such revealed preference data makes it difficult to pinpoint a reasonable value for acceptable detour rate, especially since the type of infrastructure is not considered, thus the modelled willingness to detour from Broach et al. was used.

For this paper, the impedance factor is multiplied by the bicycle travel times for the segment (one for each direction), as opposed to distance used by Cervero et al. The bicycle travel time takes account of topography, and thus provides a benefit over distance when estimating bicycle route choice, particularly in hilly environments common place in Norway. The impedance factors adopted for each LTS level are as follows: 1 for LTS 1; 1.07 for LTS 2; 1.14 for LTS 3; 1.20 for LTS 4 . Thus if a route with LTS 3 is adjacent to an LTS 2 route, the impedance factor will make the weighted travel time on the LTS 3 route appear 7\% longer than the LTS 2 route (since 1.14/1.07=1.07). The routing algorithm seeks the route with shortest weighted travel time, and will therefore select the LTS 2 route, all else being equal. The selected route is used for subsequent calculations of travel distance.

Routing pedestrians and car drivers using the shortest travel time path is a simplification that ignores variation in route choices amongst these users. For pedestrians, however, the simplification is not entirely unrealistic, as existing research suggests that between two-thirds and three-quarters of pedestrians choose routes that they believe to be the quickest [53]. For car drivers, research suggests that the quickest path is only chosen $40 \%$ of the time, however, in most cases, drivers seek to minimise their perceived travel time [54].

The literature on public transport route choice acknowledges that travel time and cost are by far the most important variables explaining choices, whilst other variables become more important for longer journeys considering multiple transport modes and comfort [55]. For this study, public transport routes are assumed to optimise travel time.

The Trondheim transport network with bicycle infrastructure attributes was created from a merger of Open Street Map data with the Norwegian National Road Database which is publically available from the Norwegian Public Roads Administration (NPRA). ${ }^{1}$

\subsection{Analytical tools}

Simple statistical methods have been used in this paper to assess the impact of the various different factors on the modal choice of employees, run in the statistical analysis software IBM SPSS Statistics 25. The Geographic Information Systems (GIS) software ArcMAP 10.6 has been used to run various calculations of commute distance and travel time for the four predominant transport modes as discussed in section 3.3. This 
has also been used to produce background maps of Trondheim and Oslo showing public transport accessibility (as shown in Figs. 1 and 2).

\section{Results}

Complete survey responses were received from 112 employees in 2015 and 90 in 2016, giving a response rate of $37 \%$ and $30 \%$ respectively. A subset of $42 \mathrm{em}-$ ployees responded to both surveys, meaning that there were in total 160 unique employees who responded. The sample was split evenly with respect to gender ( $49 \%$ respondents female), and there was a large spread of ages between 18 and 65 with a median of 43 years. Information on the sample representativeness was not available. The majority of respondents (70\%) had higher education, over 90\% had access to a car they could use on a daily basis and $75 \%$ had access to a bicycle in working condition.

\subsection{Mode share and case comparison}

In general the Adresseavisen office relocation resulted in large increases in the percentage of employees commuting by bicycle (from 10 to $28 \%$ ) and on foot (from 6 to $15 \%)$, however the changes were much less pronounced for female employees (from 15 to $22 \%$ cycling and 7 to $11 \%$ walking). The change in use of public transport meanwhile (from 12 to 32\%), was approximately equal across genders. The changes in modal split suggest that men are more willing or able to adapt their means of travel, although the results do not explain why this is the case. The changes in transport modal share (walking, cycling, public transport, car/motorcycle) were assessed for independence using a Chi-square test which revealed a significant difference between the two survey years, $\chi^{2}$ (3) $=36.39, p<.001$, phi $=0.44$.

Considering the mode choices before and after relocation, 195 valid responses were received (109 from 2015 and 86 from 2016). A multinomial logistic regression model was used to determine which factors were significant in explaining the mode choice of all employees, with the explanatory variables that are significant at the 95\% confidence level included in Table 1 below. Due to their low frequencies, walking and cycling were combined into a single mode choice for the final model estimation.

Tested non-significant variables included gender, age, education, number of toll ring crossings, working time, perceptions of bicycle safety, provision of bicycle infrastructure along the shortest path, self-reported mode sensitivity to additional trips, response year, number of public transport changes and travel times with different modes of transport. Many of these variables are known to be relevant predictors of mode choice from other studies but did not appear significant in the current study due most likely to the small sample size. The travel time estimates with different modes of transport were omitted due to collinearity with distance. Collinearity also explains the non-significance of some other variables, especially the provision of bicycle infrastructure along the shortest path. Here there exists a positive association between the infrastructure provision and total commute distance (due potentially to the bicycle facilities commonly found along arterials in Trondheim which are more frequently utilised on commute journeys).

The sign of the parameter estimate $b$ in Table 1 indicates the direction of the relationship on the dependent variable mode choice. As an example, a commute

Table 1 Results of the multinomial regression model for active versus motorised transportation modes

\begin{tabular}{|c|c|c|}
\hline Parameter & $\begin{array}{l}\text { Pedestrian/Bicycle: Public transport } \\
\text { b (Standard Error - SE) }\end{array}$ & $\begin{array}{l}\text { Pedestrian/Bicycle: Car/motorcycle }{ }^{\beta} \\
\text { b (Standard Error - SE) }\end{array}$ \\
\hline Intercept & $0.067(0.916)$ & $0.070(0.877)$ \\
\hline Bicycle availability & $-1.948(0.731)^{* *}$ & $-2.39(0.677)^{* * *}$ \\
\hline Car availability & $-0.654(0.657)$ & $2.375(0.724)^{* *}$ \\
\hline Child $<10$ years & $0.381(0.615)$ & $1.189(0.530)^{*}$ \\
\hline Distance $<2 \mathrm{~km}$ & $-2.579(1.169)^{*}$ & $-1.066(0.636)$ \\
\hline Distance $>7.5 \mathrm{~km}$ & $2.542(0.652)^{* * *}$ & $2.337(0.580)^{* * *}$ \\
\hline Paid Parking & $1.435(0.627)^{*}$ & $-1.879(0.515)^{* * *}$ \\
\hline McFadden $\mathrm{R}^{2}$ & 0.381 & \\
\hline-2 (Log likelihood) & 90.161 & \\
\hline \multirow[t]{2}{*}{ Sample size } & 195 & \\
\hline & $\begin{array}{l}{ }^{\mathbf{a}} \text { Choose public transport over continuing to } \\
\text { bicycle or walk to work }\end{array}$ & $\begin{array}{l}{ }^{\boldsymbol{\beta}} \text { Choose car/motorcycle over continuing to } \\
\text { bicycle or walk to work }\end{array}$ \\
\hline
\end{tabular}

Model $X^{2}(12)=148.49, p<.001 .{ }^{*} p<.05,{ }^{* *} p<.01,{ }^{* * *} p<.001$ 


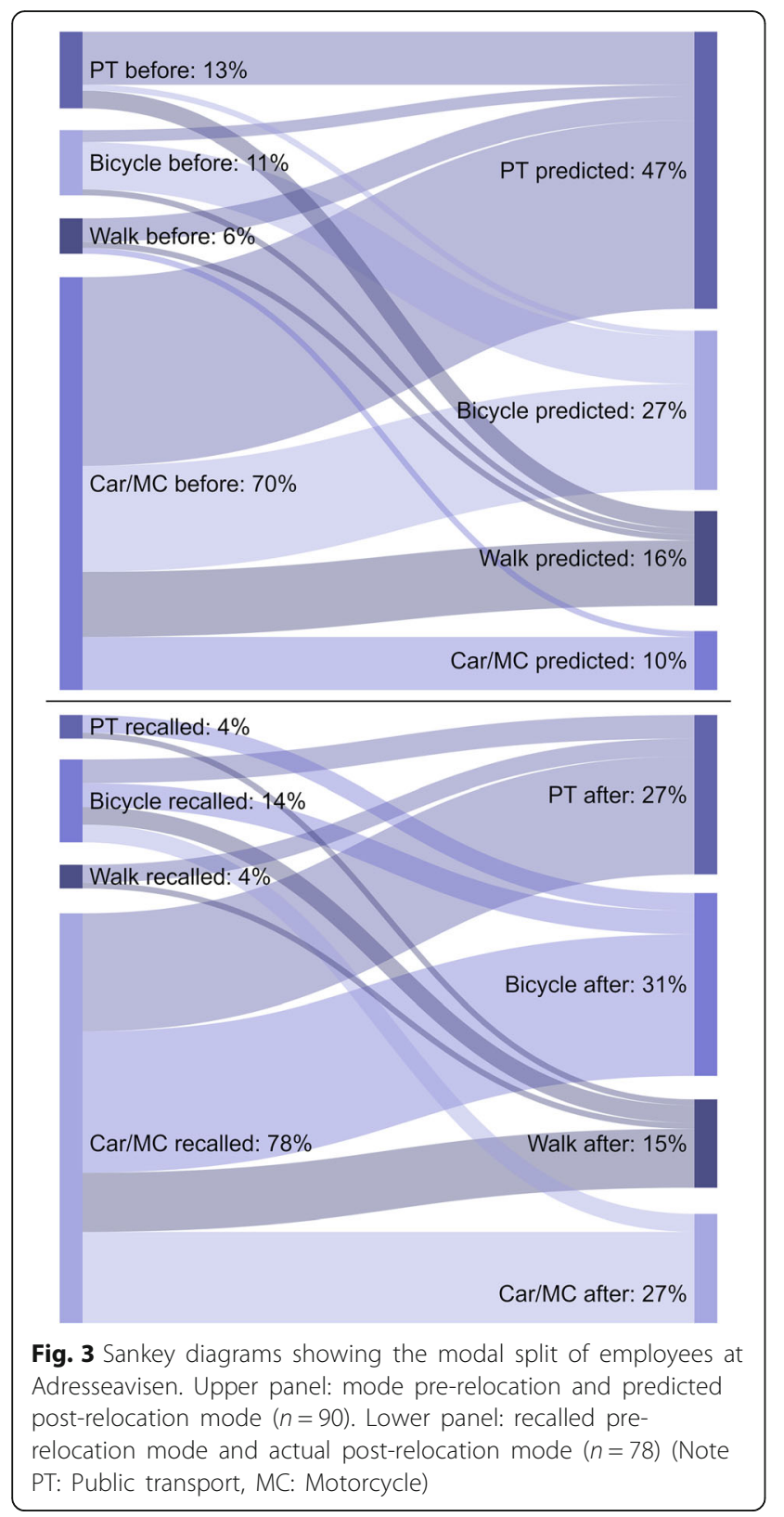

distance of more than $7.5 \mathrm{~km}$ increases the likelihood of the selection of either public transport or car/motorcycle over the reference category of walking and cycling, as indicated by the positive values of $b$. This can alternatively be interpreted as a decreased likelihood to walk or cycle for longer distances. On the other hand, the availability of a bicycle or the necessity to pay for car parking will decrease the likelihood of car/motorcycle selection relative to cycling and walking, as shown by the negative parameter estimates. The model overall had a pseudo $R^{2}$ value (McFadden) of 0.381 , suggesting a reasonable degree of explanation is provided by the combination of variables in Table 1.
In the pre-relocation survey, respondents were asked about their expected travel mode (which occurred 1 month later), whilst respondents one year later were asked to recall their most used travel mode prior to relocation. Since the surveys were conducted in the summer the questions about expected and recalled modes were also about the summer. The responses are plotted in a Sankey diagram in Fig. 3 below. The figure illustrates that many more $(47 \%$ of before sample) expected to travel by public transport (PT) than actually did (27\% after). Flows are difficult to compare with high precision since the two survey samples are cross-sectional, however close to half the former car drivers expected to be using public transport (32\% of the total before sample) compared to the one quarter that actually swapped to public transport ( $20 \%$ of the total after sample). The actual levels of walking and cycling are approximately equal to those predicted.

The before and after impacts for the Adresseavisen case study are compared with the most recent comparison case, the private insurance company Gjensidige, which relocated only 2 years earlier. This data is presented in Fig. 4 together with the commuting data for the corresponding boroughs extracted from the Norwegian National Travel Survey (NNTS) [56]. Both companies have a relatively high degree of specialisation, although this is arguably greater for Adresseavisen due to its dominance amongst newspaper publishers in the county of Trøndelag.

The commuting patterns at both offices before and after the relocation is very similar to the NNTS commuting behaviour in the respective boroughs (bydeler in Norwegian), although the match is better for the Adresseavisen case. This indicates that although company function can vary significantly within a borough (as it does in the NNTS dataset), the spatial features of the area such as accessibility with various modes and parking availability significantly influence the commuting behaviour. There are however differences in the levels of walking and cycling between the two cases and their boroughs. Considering the combination of bicycling and walking as active transport, the differences diminish.

The tendencies in Fig. 4 are corroborated by results from Gjensidige's earlier relocation out of the city in 1991 which also used borough control groups [23]. The control groups were derived from a 1990 travel survey related to the impact of toll cordons in Oslo. Similarities between the control and actual modal split are clearly evident before relocation (when located in the Oslo inner city), however significant differences $(p<.05)$ appear for motorised modes post-relocation (to Lysaker). Combined walking and 


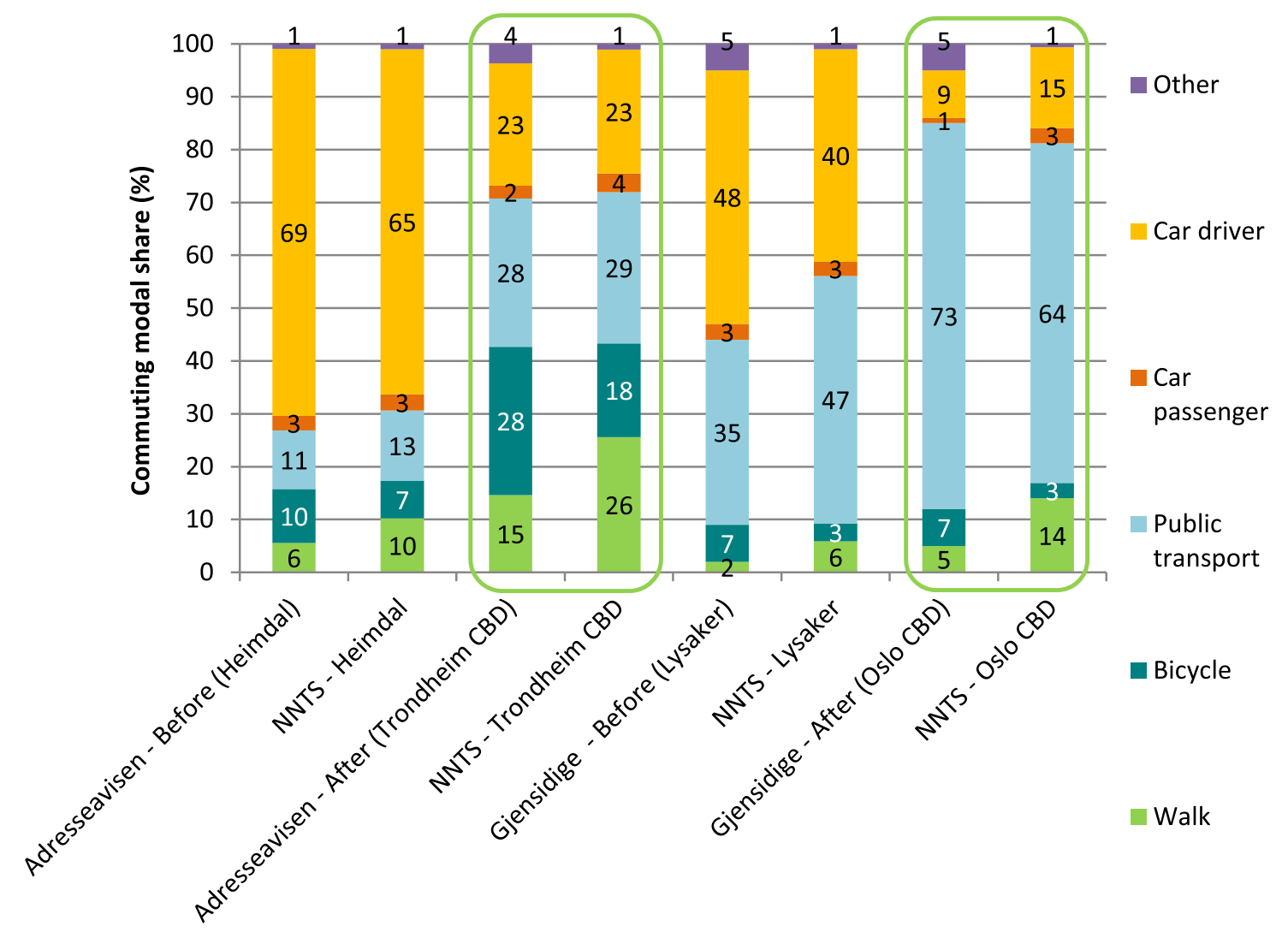

Fig. 4 Commuting transport modal split before and after two central office relocations in Norway: Adresseavisen and Gjensidige. The survey results for both companies are paired with the commuting modal split of the same boroughs using data from the Norwegian National Travel Survey (NNTS) [56]. Note NNTS data for commuting journeys are restricted to those starting/ending in the same and immediately adjacent boroughs ('bydeler') at each respective company location

bicycle modal share was however very similar between the Gjensidige locations and their respective controls in 1991 (14\% active transport modal share for both of Gjensidige's locations, and $11 \%$ for both the controls).

In Figs. 5 and 6, walking and cycling modal split for the case study and three comparison cases is plotted against distance from city centre. Distance was chosen in part due to its simplicity and since it remains constant over time, which is not the case for most other measures of accessibility. The figures show that rates of walking and bicycling increase more prominently in Trondheim than Oslo. The NNTS data from 2014 suggests that walking rates in both cities are similar (Trondheim 28\% and Oslo 32\%), however, Trondheim has nearly double the bicycle modal share of Oslo $(9 \%$ vs. 5\%) [56]. A potential explanation can relate to the average commute distance to work. Since Oslo is more than three times larger than Trondheim, the urban area and potential spread of employees is also higher, making active travel less likely.

\subsection{Travel distance and travel time}

An independent samples t-test was performed on stated commute distances and times provided by Adresseavisen employees. Stated distance to work was on average less in the city centre location $(M=9.17$ $\mathrm{km}, \mathrm{SE}=1.29)$ than the former location in the south of Trondheim $(M=13.99 \mathrm{~km}, \mathrm{SE}=1.27)$. The difference, $4.82 \mathrm{~km}, 95 \%$ CI $[1.25,8.40]$ was significant $\mathrm{t}(183)=2.661, p=0.008$. The stated travel time did not exhibit any changes significant at the $95 \%$ confidence level.

The distance to work was also calculated according to the LTS weighted shortest path in GIS from the 160 home locations provided by respondents. This distance was less to the new central location $(\mathrm{M}=8.44 \mathrm{~km}, \mathrm{SE}=$ $0.76)$, compared to the former suburban location $(\mathrm{M}=$ 10.58, $\mathrm{SE}=0.62$ ), and the difference, $2.14 \mathrm{~km}, 95 \% \mathrm{CI}$ $[1.04,3.23]$ was significant $t(159)=3.847, p<.001$. Interestingly the perceived commuting distance to the suburban workplace location $(13.99 \mathrm{~km})$ was substantially longer than the actual (calculated) distance $(10.58 \mathrm{~km})$, a 


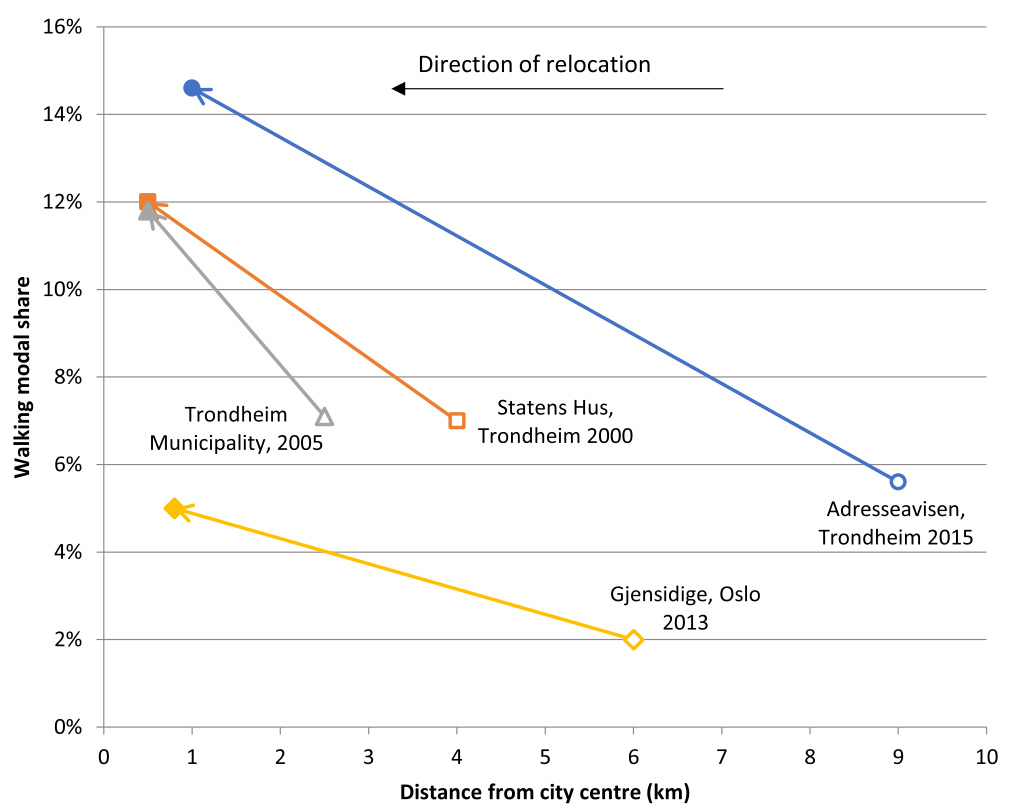

Fig. 5 Pedestrian modal share for commuting journeys before and after relocation from suburbs to the inner city

difference which diminishes when considering the inner city workplace distances. Calculating commuting distance for the case study is elaborated upon in Section 3.3.

Since the distance and walking times are direct functions of each other (assumed average walking speed of $5 \mathrm{~km}$ per hour), the walking time had the same significant reduction as walking distance ( $p$ $<.001)$.

The mean LTS adjusted cycling time (see Section 3.3) is reduced from $43.6 \mathrm{~min}(\mathrm{SE}=2.5)$ at the former location to $29.6 \mathrm{~min}(\mathrm{SE}=2.9)$ in the present central location. The reduction of $14.0 \mathrm{~min}, 95 \% \mathrm{CI}[10.0,18.0]$ was significant $\mathrm{t}(159)=6.8, p<.001$.

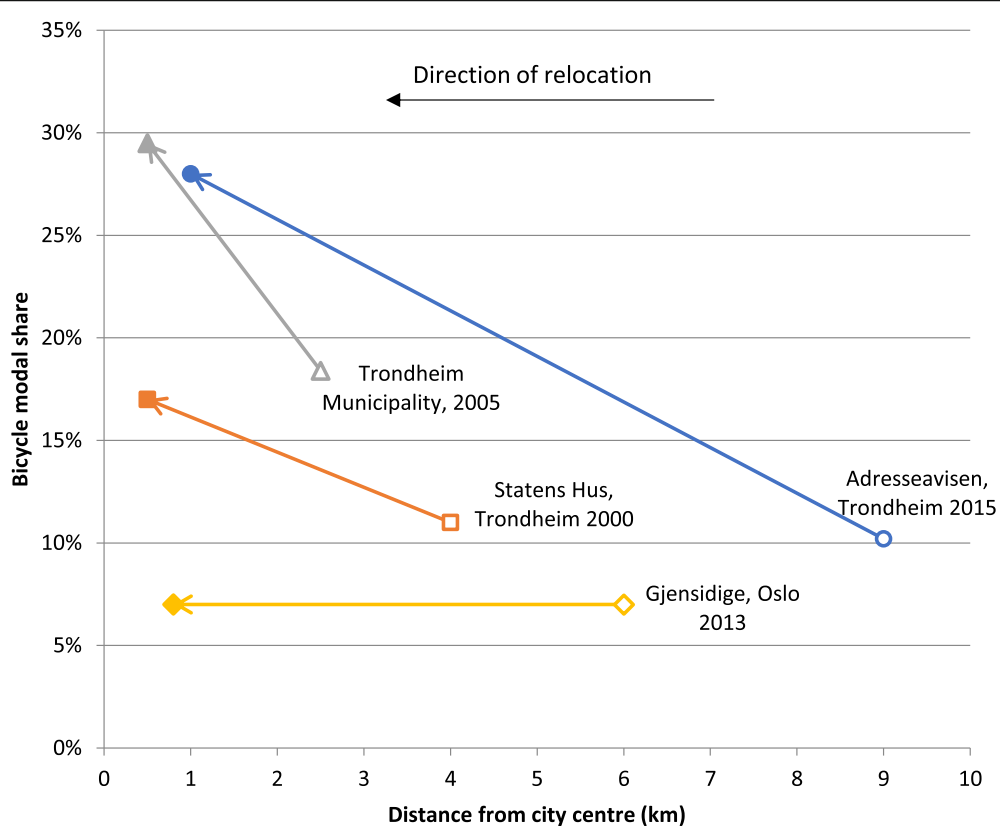

Fig. 6 Bicycle modal share for commuting journeys before and after relocation from suburbs to the inner city 


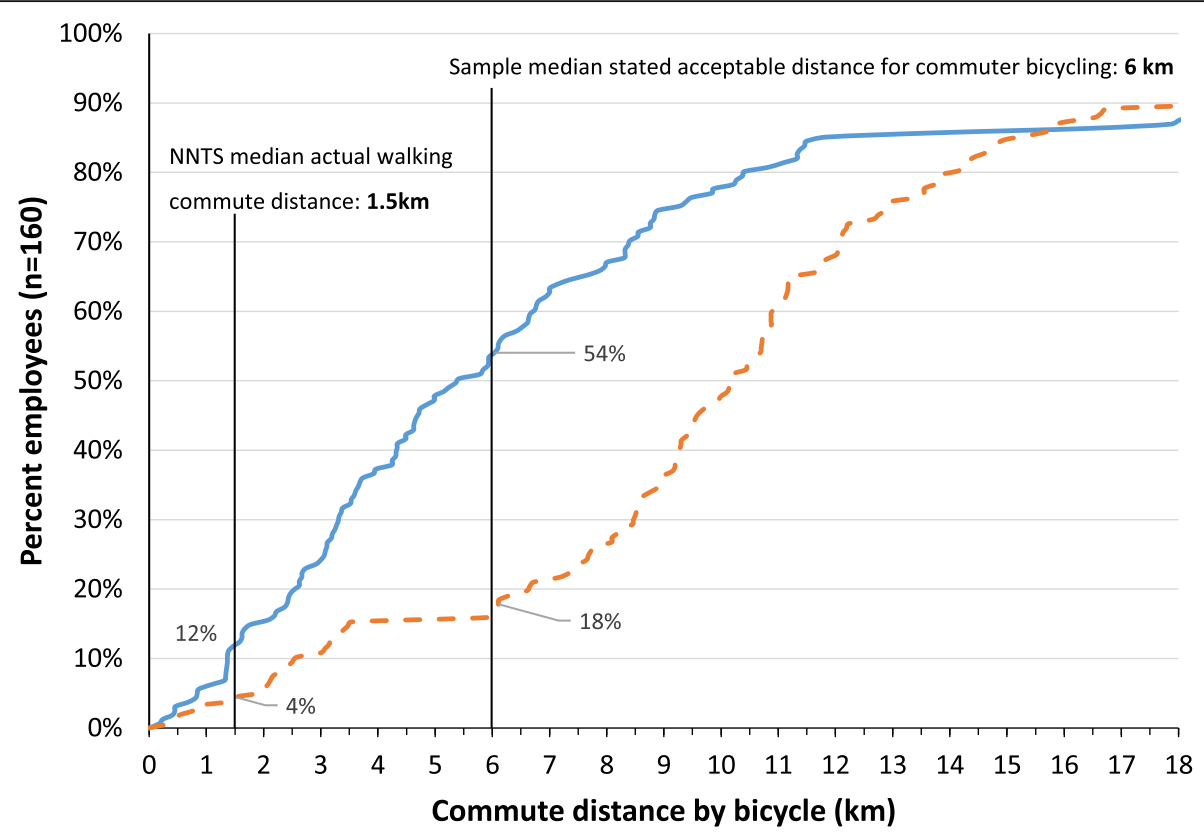

New inner city location (Solsiden) - - - Former suburban location (Heimdal)

Fig. 7 Cumulative distribution of commute distance from unique Adresseavisen employee addresses $(n=160)$ to the former and present location. Distances are calculated from a GIS operation minimising the Bicycle Level of Traffic Stress (LTS)

A significant reduction $[\mathrm{t}(159)=8.5, p<.001]$ was also found in public transport travel time from home to work (in minutes) was observed during the relocation from the suburbs $(M=49.8, \quad S E=3.0)$ to the city centre $(\mathrm{M}=38.3, \mathrm{SE}=3.3)$. The reduction, $11.5 \mathrm{~min}, 95 \% \mathrm{CI}$ $[8.8,14.1]$ includes walking to and from stops, waiting and in-vehicle time. Interestingly, although public transport accessibility is greatly improved at the new location, the number of legs in the fastest possible public transport journey did not change to a significant degree $(p \geq .05)$.

The mean calculated driving time after relocation (based on the assumption that cars travel at $90 \%$ of posted speed limits) reduces by $20 \%$ from 14 to $11 \mathrm{~min}$, however, the difference was not significant $(p=0.303)$. If intersection and congestion delays were also taken into account when calculating driving time, the difference would likely diminish since the inner city is more susceptible to delays of this nature and thus travel time following relocation would increase.

\subsection{The potential for cycling and walking following relocation}

As discussed in Section 2, travel distance is not a reliable indicator of change between urban environments on its own. In the Adresseavisen case, distance is shown to significantly decrease after relocation back to the city. This allows us to observe potential for cycling and walking. In Fig. 7, the cumulative distribution curves of commute distance are shown for the former and present workplace locations of Adresseavisen. Distances are calculated as described in Section 3.3.

The median maximum distance survey participants were willing to cycle was $6.0 \mathrm{~km}(n=126)$ and a median walking distance of $1.5 \mathrm{~km}$ applies for NNTS respondents in Trondheim who walk to work (in lieu of maximum threshold information from the sample). These two tolerance estimates for walking and cycling distance are depicted as two vertical lines in Fig. 7 above. The number of people who are within 'cycling threshold' from the new workplace thus increases from $18 \%$ to $54 \%$. Similarly the number of people within the 'walking threshold' triples from 4 to $12 \%$ following the relocation. This difference integral between the two cumulative curves also allows one to understand the walking and cycling potential of the new location (assuming that employees' home locations do not change in the short term). In reality, there is no fixed limit on acceptable distance, as this depends 
on individual preferences, but the relocation illustrates the impact of shorter distances on walking and cycling potential.

An alternative method to consider the potential is to use the ratio of car travel time against cycling, walking and public transport. To illustrate this, the average ratio between bicycle travel time and driving time reduced from 3.5 to 2.4 when relocating from Heimdal to Solsiden. For public transport (including stop access/egress, waiting and in-vehicle time) the result is 3.6 to 3.1. Reduction in these ratios indicates decreasing competitiveness of car travel. The ratios are influenced by both lower average driving speeds in inner city areas (more intersections, traffic calmed streets and lower speed limits) and reduced travel time by bicycle or public transport. However, this effect is likely underestimated since the routing method used to calculate driving times does not take consideration of delays resulting from intersections or congestion (which are more frequent/likely to impact the inner city location).

\subsection{Vehicle Kilometres travelled (VKT)}

The car VKT is calculated by summing the distance driven by employees. Using the average car VKT per respondent for both survey periods allows an estimation of the total car VKT for all 300 employees. Driving distance is modelled as for walking distance using the shortest travel time path in GIS, meaning that actual driving distances are likely longer (additional trips and detours are excluded). For the Adresseavisen case study, the 300 employees drove in total $5822 \mathrm{~km}$ daily to and from the suburban location in 2015, compared to $1787 \mathrm{~km}$ to the inner city location in 2016. This represents a 69\% reduction in car VKT, reflecting the mode shift away from cars discussed in section 4.1 and the reduction in commute distance (see section 4.2).

\subsection{Additional trip frequency}

The total number of additional trips, or trips that are combined with the journey to or from work, increased following the relocation of Adresseavisen employees. The total number of additional trips in the suburban location $(\mathrm{M}=0.83, \mathrm{SE}=0.08)$ was lower than the inner city location $(\mathrm{M}=1.27, \mathrm{SE}=0.11)$. The difference, $-0.44,95 \%$ CI $[-0.71,-0.18]$ was significant $\mathrm{t}(171)=-3.275, p=0.001$. Respondents were also asked if they felt additional trips generally affected their choice of transport mode, however, this did not change significantly before and after relocation $(p \geq .05)$.

\subsection{Parking}

In the after study for Adresseavisen, respondents were asked about the availability of different parking types at the new workplace, whilst they were previously questioned about their willingness to pay for parking in anticipation of the move. This showed that $31 \%$ of employees were willing to pay for parking at the new location. This illustrates the importance of parking cost on transport mode choice given the other 69\% were not willing to pay for this service. The after study showed that $24 \%$ of employees received or acquired free parking. This is representative of the Trondheim city centre where $26 \%$ of all employees in the central 'Midtbyen' district state that they have access to free parking, mostly subsidised by their employer (Trondheim [57]).

Table 1 displays the results of a multinomial logit model in which parking is shown to have significant effects on the choice of transport mode (comparing active to both public and private motorised transport). For the comparison of active transport with car or motorcycle, the relationship is strongly significant $(p<.001)$ in the expected direction: paid parking reduces the likelihood of driving to work. Comparing public and active transport modes also yields a significant relationship in which paid parking increases the likelihood of public transport commuting (significant at the 95\% confidence level, to be discussed further in Section 5.4).

\subsection{Demographic variables}

The survey asked participants to respond to some questions not directly connected to travel behaviour but that could be confounding factors if found to have changed during the relocation. These questions concerned the maximum acceptable distance to cycle, the typical number of working hours and perceived safety of bicycling, however, none of these changed significantly following the relocation.

The multinomial logit model presented in Table 1 shows that having a child under the age of 10 years positively influences the decision to drive to work compared to commuting by bicycle or on foot (significant at the $95 \%$ confidence level). This is likely connected to the additional trips associated with accompanying young children to and from school/kindergarten or other activities which is not always practical in combination with the journey to work if this is by an active mode of transportation.

\section{Discussion}

\subsection{Reduction in distance to work and VKT}

Distance between workplace and the city centre can be considered as a proxy for accessibility, and has 
been shown, together with the density of population and jobs at the workplace location, to be strongly significant $(p<.001)$ in explaining the average commute distance in the Norwegian cities of Oslo, Trondheim and Bergen [58].

The relocation of Adresseavisen resulted in a significant reduction to the commute distance (from 10.6 to $8.4 \mathrm{~km}$ ) for employees. A travel behaviour survey of 925 employees from 20 companies in Trondheim showed that peripheral and central locations had similar average commute distances $(9.6 \mathrm{~km}$ and $8.7 \mathrm{~km}$ respectively) to Adresseavisen's former and new location [59]. The 2012 relocation of a university institute in Karlsruhe, Germany from a peripheral location to the inner city exhibited a comparable reduction in travel distance to Adresseavisen (from 30 to $27 \mathrm{~km}$ ), accompanied also by a reduction in travel time [30]. Given the high degree of specialisation of universities, the literature suggests that we can expect the average commuting distance to be greater [34, $60]$. For both cases, however, the reduction in the commuting distance appeared conducive to the observed increases in walking, bicycling and public transport usage.

Car VKT for the Gjensidige relocation were reduced by $82 \%$ despite no significant change in the distance being commuted by employees [6]. The equivalent calculation for Adresseavisen (see section 4.4) was a 69\% reduction in car VKT, combined with the aforementioned reduction in commute distance. Thus commute distance alone cannot explain the changes in car VKT but in combination with restrictive measures for car use and the extent to which alternatives for non-motorised travel are satisfactory for employees. For decentralisation cases, commute distances have been found to increase substantially as a result of relocation from the city centre and this was the largest contributing factor to the overall increase in VKT ([10], p. 1069).

With a reduction in distance and improvement in accessibility on foot and by bike comes an increase in active transport use. In some cases, improved bicycle network connectivity can lead to increased bicycle modal share despite increased average commuting distances, as was the case for the relocation of Ericsson's headquarters towards the inner city of Copenhagen (City of Copenhagen 1993 in [29]). Public transport access was, however, not significantly improved, and no significant changes were therefore witnessed for the public transport modal share.

\subsection{Travel time}

As a key supply variable influencing the transport mode, travel time with various transport modes was considered in the multinomial logit model, however, due to its strong collinearity with distance, was removed from the final model. Distance was chosen over travel time due to its stability and connection to policies related to land use, although preliminary logit models with more covariates suggest that travel time by car was slightly better at predicting travel mode for the Adresseavisen employees (potentially since this is the dominant transport mode for the full dataset).

The stated travel time did not change significantly for the Adresseavisen employees, which is partly explained by the modal shift from car to slower transport modes for many employees and non-significant change in travel time for those who continue to drive to the new workplace.

Increased levels of active transport can have considerable benefits for the wellbeing of employees. Increased time spent cycling and walking provides health benefits such as improved cardiorespiratory fitness [61] and reduced stress [62]. In a British study, employees were found to have significantly improved overall psychological well-being in connection with switching from car to active travel means [63].

Other research comparing the behaviour of different modes of commuters suggests that bicycle commuters have a higher quality of life than other commuters $[64,65]$. Although public transport users do not receive the same health benefits as cyclists or pedestrians from their primary mode of transport, one study found that they spend on average $19 \mathrm{~min}$ per day walking to and from stops [3].

\subsection{Additional trips increase}

The Adresseavisen case showed that the central relocation significantly increased the number of additional trips taken on the way to or from work (from 0.8 to 1.3$)$. This additional trip behaviour, also known as trip-chaining, is more probable given the increased diversity of activities in proximity to a central workplace than a peripheral one. This argument is corroborated by findings from an office decentralisation in Melbourne, Australia, which showed a $10 \%$ reduction in the number of daily activities per person connected to the work trip after relocating out of the city (from 2.2 to 2.0$)$ [11].

The impact of additional trips connected to the commute is less clear. Reduced car commuting from one member of a household can subsequently free up a car for other household members. The increase in the total number of additional trips associated with "placing shops and services near workplaces and at neighbourhood gateways could induce trip-chaining 
and more efficient automobile travel" suggest Cervero and Duncan [46]. In a study of household travel behaviour in the Puget Sound area, USA, Krizek [66] found that a shortened commute was correlated with both lower VKT and higher frequency of trips, suggesting that "households who shorten their commute are more prone to participate in more tours through the course of the day".

For trip-chaining, independent of modal shift, to have a positive effect, at least two null hypotheses should be upheld. The first is that the number of non-commuting trips remains constant during a relocation. This is not always the case, as additional trips may be performed out of convenience and accessibility at the new central location (increased choice of non-work destinations near to the new workplace). The second null hypothesis, as discussed by Schneider, is that the any trips that get combined with the commute are not independently "walkable" or "bikeable" ([67], p. 70). To illustrate this idea, consider that a journey from home to the shops and back was previously walked, but after being 'trip-chained' with the much longer commute, is no longer walkable and is therefore driven. In this example, even if the total number of trips performed is reduced due to trip-chaining, the VKT is not reduced due to the substitution of a walking trip with a vehicle trip.

\subsection{Parking}

In section 4.6, the reduction in Adresseavisen employees' car use as a result of paid parking was presented. Whilst the inverse correlation between parking costs and car usage is well supported in the academic literature [68-71], the other finding (significant at the $95 \%$ confidence level) that paid parking increases the likelihood of public transport commuting over active commuting is less intuitive. This finding reflects more than simply the relocation itself, as the relocation covariate was tested to be non-significant in the multinomial logistic regression model. Neither public transport users, bicyclists nor pedestrians are required to pay for parking. The unintuitive result may be due to collinearity between paid parking and public transport accessibility in the Adresseavisen case which is stronger than any collinearity between paid parking and walkability/bikeability. The former suburban workplace location had ample free parking and relatively poor public transport, whilst the new inner city location has free car parking for a minority of employees in combination with much improved public transport offering (see section 4.2 regarding public transport travel times).
Thus, paid parking, due to its close correlation with better public transport services, can explain why public transport is more attractive relative to bicycling and walking.

Travel behaviour for the cases discussed in this study is dependent on a mix of factors that influence the cumulative attractiveness to choose one mode of transport over another. When car accessibility is left unchanged, car users may not see any reason to change their mode of transport, despite the increased competitiveness of alternatives. An example of this is the steady car modal share of Ericsson following relocation from Brøndby in Copenhagen's western suburbs to a more central location at Sydhavnen with unchanged car parking and public transport accessibility (City of Copenhagen 1993 in [29]).

Although there are many benefits of reduced car use in cities, free or highly subsidised parking from municipalities and employers remains a very common phenomenon. In the early 1990s the extent of the parking subsidy in the USA was estimated to lie between 1.2 and $3.7 \%$ of the nation's gross domestic product, a level roughly equal to the nation's annual defence expenditure ([71], p. 207).

\subsection{Policy implications}

The former tendencies towards intra-city decentralisation have been largely reversed in Trondheim and Oslo for the case of compact transport-generating urban land-uses like offices. However, for more land-intensive workplaces, such as developments in the Forus area between the Norwegian cities of Stavanger and Sandnes, debate continues regarding the benefits of decentralisation [72]. Economic and political arguments play a greater role in the relocation of such public services relative to commercial offices, given their important societal role and much greater land acquisition costs involved.

To assess the direct impacts of compact urban development policies on workplace travel behaviour is difficult. Norwegian cities are in general densifying in line with national and regional policies for integrated transport and land use. However, the potential is not fully utilised. For example in Trondheim, in the period 2000-2012 the "potential for densification, in terms of population density, was equal to the population increase (19.7\%) if no new land was added for urban use; however, the actual outcome was 7.6\%" [73].

Density, parking costs, subsidies towards sustainable transport amongst many other policies all contribute to lower traffic volumes from centrally located workplaces [33]. The multinomial logit model for the Adresseavisen commuter mode choice (see Table 1) 
reveals the importance of commute distance and parking costs on transport mode, together with access to different means of transport (car and bicycle in particular, but potentially also public transport as discussed in section 5.4). All of these factors are connected to the density of the company location (amongst other land use variables). As Tennøy [35] points out: "[in] European cities, there is a clear and strong covariance between centrality and density, parking access, public transport accessibility, and the number of people living within walking- and bicycling distances." The disaggregation of factors is complex due to this covariance, but empirical evidence points repeatedly towards the same conclusions: central workplace locations with good public transport accessibility will create far more opportunities for public and active transport than peripheral workplaces with little competition to workplace accessibility by car.

It should be noted that commuting behaviour is affected by the location of both workplace and residence. Whilst workplace locations are determined by such policies as compact urban development, the choice of residential location is affected by different political and economic factors. It is worth considering that if residential relocation is subject to market restrictions, then relocations (including those towards workplaces) are impeded. The reduction of stamp duty is proposed by van Ommeren as a potential policy change that can reduce the economic burden of moving home, thus giving employees an improved opportunity to reduce their commuting distance [60]. Policy initiatives that seek to reduce excessive commuting or private car usage can thus be focussed on multiple areas in terms of relocation or workplaces and homes, together with a suite of policies affecting the costs or travel times of different transport modes.

\subsection{Limitations}

This study has several limitations that could be amended in future studies concerning travel behaviour in connection to land use changes. The ideal circumstance for before and after research studies is to have a panel study design in which the same group of participants responds to both surveys (fixed sample rather than population- or cross-sectional sampling). The panel group for this study was only 42 employees, making it too small to perform regression analyses upon.

A second limitation concerns the mode choice modelling possibilities with the dataset. Since the sample size is relatively small, there are certain combinations of factors that would often be used in a mode choice model for which there are very few or no individuals. Certain variables known from the literature to influence mode choice appeared as non-significant in the multinomial logistic regression performed in this study, due in large part to the sample size. It may also be of interest to consider how the relocation affects route choice, or alternatively to test the assumption of stability of supply variables such as distance or parking availability before and after relocation. The sample size and data collection approach restricts the opportunities to perform such tests, so future studies may address these limitations with a larger dataset, such as a national travel survey or in connection with a larger workplace relocation.

\section{Conclusion}

This study considers the relocation of Adresseavisen to the inner city of Trondheim in comparison to three similar workplaces in the Norwegian cities of Trondheim and Oslo. The cases demonstrate substantial increases in walking, cycling and public transport commuting, and in the case of Adresseavisen, the numbers of cyclists, pedestrians and public transport users approximately tripled following relocation. Although the function of workplaces can vary significantly within a city neighbourhood or borough, the spatial attributes of the workplace destination are found to be a dominant factor in determining the modal split of employees. Level of Traffic Stress weighted bicycle distance to work was used to demonstrate the potential for cycling and walking before and after relocation. The number of employees living within acceptable cycling and walking commute distance was found to triple after relocation, roughly in line with the actual changes in numbers of bicycle and pedestrian commuters. In addition to commute distance, the multinomial logit model revealed that access to different transport modes (especially car and bicycle) were significantly associated with the choice of mode. Paid car parking also appeared to influence mode choice, increasing the likelihood to walk or bicycle to work significantly, whilst having a child under the age of 10 was associated with a decreased likelihood of making an active transport commute.

\section{Endnotes}

${ }^{1}$ NPRA public dataset for Norwegian road network merged with Open Street Map network: ftp://vegvesen.hostedftp.com/ StatensVegvesen/vegnett/

Sykkeldata/ 


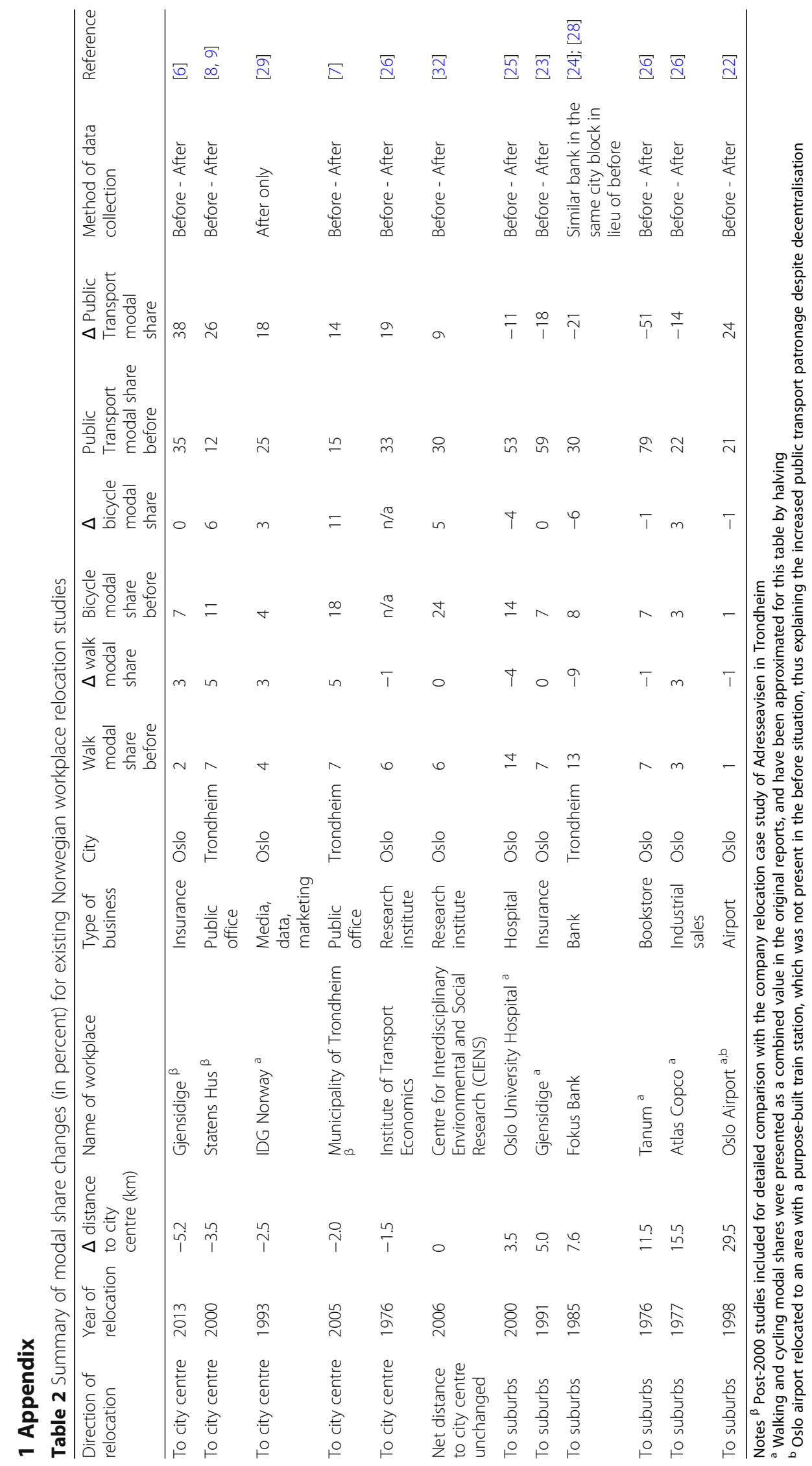




\section{Additional file}

Additional file 1: Case study survey responses (Adresseavisen). (XLSX $79 \mathrm{~kb})$

\section{Abbreviations}

Cl: Confidence Interval; GIS: Geographic Information Systems; LTS: Level of Traffic Stress; NNTS: Norwegian National Travel Survey; NPRA: Norwegian Public Road Administration; SE: Standard Error; VKT: Vehicle Kilometres Travelled

\section{Acknowledgements}

The authors would like to thank Tor Medalen, Marianne Knapskog and Petr Pokorny for their input during the creation of this article.

\section{Funding}

Open access funding provided by NTNU - Norwegian University of Science and Technology.

\section{Availability of data and materials}

The datasets generated and analysed during this study are included in this published article (Additional file 1).

\section{Authors' contributions}

Conceived and designed the study: RP. The collection, analysis and/or interpretation of data: RP, YF. Wrote the manuscript: RP. Edited and revised the manuscript: RP, YF. Both authors read and approved the final manuscript.

\section{Competing interests}

The authors declare that they have no competing interests.

\section{Publisher's Note}

Springer Nature remains neutral with regard to jurisdictional claims in published maps and institutional affiliations.

\section{Received: 20 March 2018 Accepted: 15 January 2019}

Published online: 21 February 2019

\section{References}

1. Stead, D., \& Marshall, S. (2001). The relationships between urban form and travel patterns. An international review and evaluation. Eur J Transp Infrastruct Res., 1(2), 113-141 Available at: http://www.ejtir.tudelft.nl/issues/ 2001_02/pdf/2001_02_01.pdf.

2. Van Wee, B., Bakker, D., \& Van Der Hoorn, T. (1997). "Office suites suit the railways": The effect of office location to public transport nodal points on passenger mobility (European Transport Forum Annual Meeting) (pp. 269282) Available at: https://aetransport.org/public/downloads/iuzrA/2219514ec450e2e42.pdf.

3. Besser, L. M., \& Dannenberg, A. L. (2005). Walking to public transit. Am J Prev Med., 29(4), 273-280. https://doi.org/10.1016/j.ampre.2005.06.010.

4. Sahlqvist, S., Song, Y., \& Ogilvie, D. (2012). Is active travel associated with greater physical activity? The contribution of commuting and noncommuting active travel to total physical activity in adults. Prev Med., 55(3), 206-211. https://doi.org/10.1016/j.ypmed.2012.06.028

5. Wener, R. E., \& Evans, G. W. (2007). A morning stroll: Levels of physical activity in Car and mass transit commuting. Environ Behav., 39(1), 62-74. https://doi.org/10.1177/0013916506295571.

6. Christiansen, P., \& Julsrud, T. E. (2014). TØI report 1344/2014. Effekter av Gjensidiges omlokalisering fra Lysaker til Bjørvika [Effects of Gjensidiges relocation from Lysaker to Bjørvika]. Oslo: Institute of Transport Economics Available at: https://www.toi.no/getfile.php?mmfileid=38240.

7. Paulsen, K. E., Kvidal, M., \& Strømmen, K. (2008). Endringer i reisevaner etter samlokalisering av kommunal administrasjon i Midtbyen \{Changes i travel behaviour after relocation of municipal administration to Midtbyen? Trondheim: Trondheim Kommune Available at: https://153.110.202.34/ attachment.ap?id=49199.

8. Meland, S. (2002). SINTEF Report STF22 A013. Flytting til nye Statens hus i Trondheim: effekter på reisevaner \{Moving to the new Statens Hus in Trondheim: effects on travel behaviour\}. Trondheim: SINTEF.
9. Meland, S. (2012). SINTEF Report A23625. Arbeidsreisen - reisevaner og utvikling. En undersøkelse knyttet til Statens hus og Teknobyen i Trondheim \{The commute - travel behaviour and development. A survey relating to Statens Hus and Teknobyen in Trondheim\}. Trondheim: SINTEF Available at: https://www.sintef.no/globalassets/upload/teknologi_ samfunn/6060/rapporter-2012/a23625_arbeidsreisen---reisevaner-ogutvikling.pdf.

10. Cervero, R., \& Wu, K.-L. (1998). Sub-centring and commuting: Evidence from the San Francisco Bay Area, 1980-90. Urban Stud., 35(7), 1059-1076. https:// doi.org/10.1080/0042098984484.

11. Bell, D. A. (1991). Office location - city or suburbs? - travel impacts arising from office relocation from city to suburbs. Transportation, 18(3), 239-259. https://doi.org/10.1007/BF00172938.

12. Cervero, R., \& Landis, J. (1992). Suburbanization of jobs and the journey to work: A submarket analysis of commuting in the San Francisco bay area. $J$ Adv Transp., 26(3), 275-297. https://doi.org/10.1002/atr.5670260305.

13. Daniels, P. W. (1972). Transport changes generated by decentralized offices. Reg Stud., 6(3), 273-289. https://doi.org/10.1080/09595237200185231.

14. Daniels, P. W. (1981). Transport changes generated by decentralized offices: A second survey. Reg Stud., 15(6), 507-520. https://doi.org/10.1080/ 09595238100185451

15. Aguiléra, A., Wenglenski, S., \& Proulhac, L. (2009). Employment suburbanisation, reverse commuting and travel behaviour by residents of the central city in the Paris metropolitan area. Transp Res A Policy Pract., 43(7), 685-691. https://doi.org/10.1016/j.tra.2009.06.004.

16. Burke, M. I., Li, T., \& Dodson, J. (2011). What happens when government workers move to the suburbs? Impact on transport of planned decentralization of employment in Brisbane, Australia. J Transp Res Board, 2255, 110-116. https://doi.org/10.3141/2255-12.

17. Sprumont, F., \& Viti, F. (2017). The effect of workplace relocation on individuals' activity travel behavior (pp. 1-20). Brisbane: World Symposium on Transport and Land Use Research Available at: http://dx.doi.org/10.5198/jtlu. 2018.1123. et al. WSTLUR.Pdf

18. Vale, D. S. (2013). Does commuting time tolerance impede sustainable urban mobility? Analysing the impacts on commuting behaviour as a result of workplace relocation to a mixed-use Centre in Lisbon. J Transp Geogr, 32, 38-48. https://doi.org/10.1016/j.jtrangeo.2013.08.003.

19. Yang, $X_{\text {., }}$ et al. (2017). Commute responses to employment decentralization: Anticipated versus actual mode choice behaviors of new town employees in Kunming, China. Transp Res Part D: Transp Environ., 52, 454-470. https:// doi.org/10.1016/j.trd.2016.11.012.

20. van Wee, B., \& van Der Hoorn, T. (1996). Employment location as an instrument of transport policy in the Netherlands: Fundamentals, instruments and effectiveness. Transp Policy, 3(3), 81-89. https://doi.org/10. 1016/0967-070X(96)00018-2.

21. Aarhus, K. (2000). Office location decisions, modal split and the environment: The ineffectiveness of Norwegian land use policy. J Transp Geogr., 8(4), 287-294. https://doi.org/10.1016/S0966-6923(00)00009-0.

22. Burheim, J. et al. (2000) PROSAM Report 70. Endringer i reisevaner til/fra hovedflyplass ved flytting fra Fornebu til Gardermoen \{Changes in travel behaviour to/from Oslo airport after moving from Fornebu to Gardermoen\}. Available at: http://www.prosam.org/index.php?page=report\&nr=70.

23. Hanssen, J. U. (1995). Transportation impacts of office relocation. A case study from Oslo. J Transp Geogr., 3(4), 247-256. https://doi.org/10.1016/ 0966-6923(95)00024-0.

24. Kollbotn, K., Langmyhr, T., \& Lervåg, H. (1993). NIBR report 1993:10. Arbeidsplassenes betydning for kollektivtrafikken - eksempel fra Trondheim. \{workplace impact on public transport - example from Trondheim\}. In Bystruktur og kollektivtrafikk: ein studie frå Trondheim (pp. 102-117). Oslo: Norwegian Institute for Urban and Regional Research (NIBR).

25. Konst, F. (2003). PROSAM Report 95. Reisevaneundersøkelsen Rikshospitalet. Før og etter flytting. \{Travel behaviour survey Oslo University Hospital. Before and after moving\}. Oslo: PROSAM Available at: http://www.prosam.org/index. php?page=report\&nr=95\#.

26. Monsen, G. (1983). Samlokalisering av bolig og arbeid: Bedriftsflytting endring $i$ arbeidsreise og energiforbruk \{co-location of home and work Company relocation - change in commute and energy consumption\}. Oslo: University of Oslo.

27. Naess, P., \& Sandberg, S. L. (1996). Workplace location, modal Split and energy use for commuting trips. Urban Stud, 33(3), 557-580. https://doi.org/ 10.1080/00420989650011915. 
28. Strømmen, K. (1996). Reisevaner ved bedrifter med ulik lokalisering. En studie av reisevaner ved Fokus Bank og TEAB i Trondheim \{Travel behaviour at differently located workplaces. A study of travel behaviour at Fokus Bank and TEAB in Trondheim\}. Trondheim: Department of City and Regional Planning, Norwegian University of Science and Technology.

29. Fosli, O. (1995). TØI note 1021/1995. Lokalisering av virksomheter konsekvenser for transport og miljø: en litteraturstudie. \{Location of companies - consequences for transport and the environment: a literature study\}. Oslo: Institute of Transport Economics (TØI-notat (online)) Available at: https:// www.toi.no/getfile.php?mmfileid=14182.

30. von Behren, S., Puhe, M., \& Chlond, B. (2016). Assessing the impacts of office relocation on travel behavior and the Organization of Activities within households (Transportation Research Board 96th Annual Meeting) (pp. 1-16).

31. Walker, I., Thomas, G. O., \& Verplanken, B. (2015). Old habits die hard: Travel habit formation and decay during an office relocation. Environ Behav., 47(10), 1089-1106. https://doi.org/10.1177/0013916514549619.

32. Tennøy, A., \& Lowry, M. (2008). TØ/ report 997/2008. Reisevaner for ansatte $i$ CIENS-bedriftene før og etter samlokalisering i Forskningsparken \{Travel survey among employees in the CIENS-institutes before and after relocation to Forskningsparken\}. Oslo: Institute of Transport Economics Available at: https://www.toi.no/getfile.php?mmfileid=10810.

33. Ewing, R., \& Cervero, R. (2010). Travel and the built environment. A metaanalysis. J Am Plann Assoc., 76(3), 265-294. https://doi.org/10.1080/ 01944361003766766.

34. Næss, P. (2012). Urban form and travel behavior: Experience from a Nordic context. J Transp Land Use, 5, 21-45. https://doi.org/10.5198/jtlu.v5i2.314.

35. Tennøy, A., Øksenholt, K. V., \& Aarhaug, J. (2014). Transport effects and environmental consequences of central workplace location. Transportation Research Procedia, 4, 14-24. https://doi.org/10.1016/j.trpro.2014.11.002.

36. Solheim, T. (1988). TØl report 0858/1988. Bilens rolle i bysamfunnet \{The car's role in urban society\}. Oslo: Institute of Transport Economics (TØI-notat (trykt utg.)).

37. Næss, P., \& Larsen, S. L. (1994). NIBR report 1994:17. Hvor jobber de som kjører mest? Energibruk og reisemiddelfordeling for arbeidsreiser ved seks bedrifter i Stor-Oslo \{Energy use and modal split for journeys to work among employees of six workplaces in Greater Oslo\}. Oslo: Norwegian Institute for Urban and Regional Research (NIBR-report) Available at: http://urn.nb.no/URN:NBN:nonb_digibok_2009072901148.

38. Brundtland, G. H. (1987). Our common future. Oxford: Oxford University Press.

39. Sætren, H. (2016). From controversial policy idea to successful program implementation : the role of the policy entrepreneur, manipulation strategy , program design, institutions and open policy windows in relocating Norwegian central agencies. Policy Sci., 49(1), 71-88. https://doi.org/10.1007/ s11077-016-9242-4.

40. Miljøverndepartementet. (1993). Statute T-5/93. Rikspolitiske retningslinjer for samordnet areal og transportplanlegging \{National guidelines for integrated land use and transport planning\}. Norway: Available at: https://www.regjeringen.no/ no/dokumenter/t-593-areal-og-transportplanlegging/id107851/.

41. Kommunal- og moderniseringsdepartementet (2014) Statlige planretningslinjer for samordnet bolig-, areal- og transportplanlegging (Governmental planning requirements for housing, land use and transport planning). Available at: https://www.regjeringen.no/contentassets/ 689bae9d728e48e8a633b024dcd6b34c/sprbatp.pdf.

42. Rolfsen, E., \& Reguleringsvesen, O. (1950). Generalplan for Oslo: et utkast lagt fram som diskusjonsgrunnlag for de kommunale myndigheter og etater og for andre interesserte \{General plan for Oslo: a draft presented for discussion by the municipal authorities and for other interested parties\}. Oslo: Oslo reguleringsvesen.

43. Hernández-Palacio, F. (2014). On the feasibility of and effectiveness of urban densification in Norway. Nordic Journal of Architectural Research, 1-35 Available at: http://arkitekturforskning.net/na/article/view/496/444.

44. Hansen, E. A., \& Harkjerr, A.-M. (2012). Kommuneplanens arealdel 2012-2024: Planbeskrivelse \{municipal land use plan 2012-2014: Plan description\}. Trondheim: Available at: https://www.trondheim.kommune.no/globalassets/ 10-bilder-og-filer/10-byutvikling/byplankontoret/kommuneplan/kpa-20122024/3_planbeskrivelse_kpa2012-24_web.pdf (Accessed: 6 Oct 2018).

45. De Bok, M., \& Van Oort, F. (2011). Agglomeration economies, accessibility and the spatial choice behavior of relocating firms. J. Transp. Land Use, 4(1), 5-24. https://doi.org/10.5198/jtlu.v4i1.144.

46. Cervero, R., \& Duncan, M. (2006). Which reduces vehicle travel more: Jobshousing balance or retail-housing mixing? J Am Plann. Assoc., 72(4), 475490. https://doi.org/10.1080/01944360608976767.
47. Agrawal, A. W., Schlossberg, M., \& Irvin, K. (2008). How far, by which route and why? A spatial analysis of pedestrian preference. Journal of Urban Design, 13(1), 81-98. https://doi.org/10.1080/13574800701804074.

48. Cervero, R., Denman, S., \& Jin, Y. (2018). Network design, built and natural environments, and bicycle commuting: Evidence from British cities and towns. Transp Policy. https://doi.org/10.1016/j.tranpol.2018.09.007.

49. Furth, P. G., \& Mekuria, M. C. (2013). Network connectivity and low-stress bicycling (Transportation Research Board 92nd Annual Meeting). Washington: Transportation Research Board Available at: http://docs.trb.org/ prp/13-0427.pdf.

50. CROW. (2016). Design manual for bicycle traffic. Ede: Centre for Research and Contract Standardization in Civil and Traffic Engineering C.R.O.W.

51. Broach, J., Dill, J., \& Gliebe, J. (2012). Where do cyclists ride? A route choice model developed with revealed preference GPS data. Transp Res A Policy Pract., 46(10), 1730-1740. https://doi.org/10.1016/j.tra.2012.07.005.

52. Hulleberg, N., Flügel, S., \& Evarsson, G. (2018). TØl report 1648/2018. Vekter for sykkelinfrastruk- tur til bruk ved rutevalg i regionale transportmodeller [empirical based infrastructure weights for bicycle route choice].

53. Guo, Z., \& Loo, B. P. Y. (2013). Pedestrian environment and route choice: Evidence from new York City and Hong Kong. J Transp Geogr, 28, 124-136. https://doi.org/10.1016/j.jtrangeo.2012.11.013.

54. Zhu, S., \& Levinson, D. (2015). Do people use the shortest path? An empirical test of Wardrop's first principle. PLoS One, 10(8), e0134322. https:// doi.org/10.1371/journal.pone.0134322.

55. Grison, E., Burkhardt, J.-M., \& Gyselinck, V. (2017). How do users choose their routes in public transport? The effect of individual profile and contextual factors. Transport Res F: Traffic Psychol Behav., 51, 24-37. https://doi.org/10. 1016/j.trf.2017.08.011.

56. Hjorthol, R., Engebretsen, Ø., \& Uteng, T. P. (2014). TØl report 1383/2014. Den nasjonale reisevaneundersøkelsen 2013/2014 - nøkkelrapport \{2013/14 National travel survey - key results\}. Oslo: Institute of Transport Economics Available at: https://www.toi.no/getfile.php?mmfileid=39511.

57. Trondheim Municipality. (2017). Kommunedelplan: energi og Klima 2017-2030 \{Municipal plan for energy and climate 2017-2030\}. Trondheim: Trondheim Municipality Available at: https://www.trondheim.kommune.no/globalassets/10bilder-og-filer/10-byutvikling/miljoenheten/Klima-og-energi/vedlegg-1-_ kommunedelplan-energi-og-klima-_-171116_endelig.pdf (Accessed: 6 Oct 2018).

58. Engebretsen, $\varnothing$., Næss, P., Strand, A. (2018). Residential location, workplace location and car driving in four Norwegian cities. European Planning Studies, 26(10):2036-2057

59. Strømmen, K. (2001). Rett virksomhet på rett sted - om virksomheters transportskapende egenskaper \{right business at the right location - About businesses' traffic generating capacities\}. Norwegian University of Science and Technology Available at: http://hdl.handle.net/11250/229734.

60. van Ommeren, J. (2000). Commuting and relocation of jobs and residences. Aldershot: Ashgate.

61. Oja, P., et al. (2011). Health benefits of cycling: A systematic review. Scand J Med Sci Sports, 21(4), 496-509. https://doi.org/10.1111/j.1600-0838.2011.01299.x.

62. Petrunoff, N., Crane, M., \& Rissel, C. (2018). A case study exploring associations of quality of life measures with Car and active transport commute modes in Sydney. In M. Friman, D. Ettema, \& L. E. Olsson (Eds.) Quality of Life and Daily Travel (pp. 183-198). Cham: Springer International Publishing (Applying Quality of Life Research). https://doi.org/10.1007/978-3319-76623-2_10

63. Martin, A., Goryakin, Y., \& Suhrcke, M. (2014). Does active commuting improve psychological wellbeing? Longitudinal evidence from eighteen waves of the British household panel survey. Prev Med., 69, 296-303. https:// doi.org/10.1016/j.ypmed.2014.08.023.

64. Páez, A., \& Whalen, K. (2010). Enjoyment of commute: A comparison of different transportation modes. Transp Res A Policy Pract., 44(7), 537-549. https://doi.org/10.1016/j.tra.2010.04.003.

65. Crane, M., et al. (2016). 'Correcting bias in self-rated quality of life: An application of anchoring vignettes and ordinal regression models to better understand QoL differences across commuting modes. Qual Life Res., 25(2), 257-266. https://doi.org/10.1007/s11136-015-1090-8.

66. Krizek, K. J. (2003). Residential relocation and changes in urban travel: Does neighborhood-scale urban form matter? J Am Plann Assoc., 69(3), 265-281. https://doi.org/10.1080/01944360308978019.

67. Schneider, R. J. (2011). Understanding sustainable transportation choices: Shifting routine automobile travel to walking and bicycling. Berkeley: University of California Berkeley. 
68. Hess, D. (2001). Effect of free parking on commuter mode choice: Evidence from travel diary data. Transp Res Rec., 1753, 35-42. https://doi.org/10.3141/ 1753-05.

69. Newman, P., \& Kenworthy, J. (2015). The end of automobile dependence. How cities are moving beyond Car-based planning. Washington: Island Press/ Center for Resource Economics. https://doi.org/10.5822/978-1-61091-613-4.

70. Pickrell, D. H., \& Shoup, D. C. (1980). Employer-subsidized parking and worktrip mode choice. Transp Res Rec., 786, 30-39.

71. Shoup, D. C. (2011). The high cost of free parking. Chicago: American Planning Association/Planners Press.

72. Naess, P., Cao, X. J., \& Strand, A. (2017). Which D's are the important ones? The effects of regional location and density on driving distance in Oslo and Stavanger. Journal of Transport and Land Use, 10(1), 945-964. https://doi.org/ 10.5198/jtlu.2017.1183.

73. Hernández-Palacio, F. (2017). A transition to a denser and more sustainable city: Factors and actors in Trondheim, Norway. Environ Innov Soc Trans, 22, 50-62. https://doi.org/10.1016/j.eist.2016.06.002.

\section{Submit your manuscript to a SpringerOpen ${ }^{\circ}$ journal and benefit from:}

- Convenient online submission

- Rigorous peer review

- Open access: articles freely available online

- High visibility within the field

- Retaining the copyright to your article

Submit your next manuscript at $\boldsymbol{\nabla}$ springeropen.com 